\title{
The Comparative Effects of Transaction Cost Economics and Resource Based View: A Technological Alliance Motivational Perspective
}

\author{
Hwan Jin Kim
}

\begin{abstract}
This paper examines the impact of two main alliance motivation theories, transaction cost economics (TCE) and resource based view (RBV), on alliance processes among Korean manufacturing high-tech ventures. Results show that TCE and RBV are complimentarily explaining the formation of inter-firm alliances. TCE variables are more related with alliance partner characteristics while RBV is more linked with partner capabilities. Both show positive effects on performance. No significant effect is found on determining an alliance governance structure. While selecting appropriate technological alliance partners show positive effects on performance, no significant effect is found between alliance governance structure and performance. Factors of both theories impacting each alliance stage and analytical explanations of such impacts are discussed.
\end{abstract}

Keywords: High-tech ventures, resource based view, technological alliance motivation, transaction cost economics. Available Online: 26-06-2016.

This is an open access article under Creative Commons Attribution 4.0 License, 2016.

\section{INTRODUCTION}

Technological alliance is increasing rapidly since 1980's (Hagedoorn, 2006). Due to fast changing and shortening life cycle of technologies and products, high-tech firms need continuous innovation. This is often achieved by cooperating with other firms in order to complement their capabilities for innovation. Many researchers have used transaction cost economics (TCE) and resource based view (RBV) to understand inter-firm alliances formation (e.g., Buvik \& Anderson, 2002; Hitt, Dacin, Levitas, Arregle, \& Borza, 2000; Lee, Yeung, \& Cheng, 2009; Lin, Yang, \& Arya, 2009; Park, Chen, \& Gallagher, 2002; Santoro \& McGill, 2005; Song, Droge, Hanvanich, \& Calantone, 2005). However, it is not yet clear which theory such as TCE and RBV is more effective in explaining the alliance formation. Some researchers tried to compare the exploratory power of TCE and RBV on alliance formation (see Chen \& Chen, 2002; Columbo, 2003; Lai \& Chang, 2010; Odagiri, 2003; Yasuda, 2005). However, the results of empirical studies are not

\footnotetext{
1 Korea University of Technology and Education, Republic of Korea. Email: maxkim@koreatech.ac.kr
} 
consistent. Some insist TCE is better predictor than RBV (e.g., Chen \& Chen, 2002; Columbo, 2003; Lai \& Chang, 2010) while others assert RBV is better (e.g., Odagiri, 2003; Yasuda, 2005).

We argue TCE and RBV are not comparative but complementary theories. Because of the multidimensionality of alliance motivation such as cost reduction, resource acquisition, networking and learning, integrative approach of motivational theories to understand the formation of inter-firm alliances is necessary. Furthermore, Silverman (1998) stressed the importance of integrative approach of TCE and RBV in the empirical studies on inter-firm alliances. Inter-firm alliance life cycle can be classified into: 1) firm motivation to form alliance, 2) finding suitable alliance partners, 3) choosing an appropriate alliance governance structure and 4) evaluating the performance of alliance (see Das \& Teng, 2000; Kale \& Singh, 2009). Alliance motivation can influence alliance partner selection (Dong \& Glaister, 2006; Niesen, 2003), governance structure (Das \& Teng, 2000; Lai \& Chang, 2010) and performance (Lai \& Chang, 2010). Yet, little attention has been paid to technological alliance motivation in alliance literature. Previous studies of alliance motivation have been focused on other types of alliances such as international, marketing, supplier and production alliances (e.g., Goerzen \& Beamish, 2005; Rothaermel \& Hill, 2005; Rothaermel \& Alexandre, 2009; Santoro \& McGill, 2005; Zahra \& Hayton, 2008; Zhou, Li, Zhao, \& (ai, 2003).

Technological alliance is defined as "the establishment of cooperative agreements aimed at joint innovative efforts or technology transfer that can have a lasting effect on the product-market positioning of participating companies" (Hagedoorn \& Schakenraad, 1994: 291). Technological alliance is a specific type of inter-firm alliances focusing on technological cooperation. Technological alliance can be classified as joint venture, joint research, technology licensing (i.e. technology license in/out, cross licensing), minority equity investment and joint production (Hagedoorn, 1990). Understanding the impact of technological alliance motivation on the selection of particular type of technological alliance partners, governance structure and performance is critical for firms to better able to choose their technological alliance partners and governance structure which will increase the success rate of alliance. In this study, we argue TCE and RBV are not competitive but complimentary theories as alliance motivation and empirically test their effects on the formation of technological alliance.

\subsection{LITERATURE REVIEW}

The most widely used alliance motivation theory to understand inter-firm alliance formation is TCE. Williamson (1991) distinguishes the organizational structures as 'market', 'hierarchy (i.e. firms)' and 'hybrid (i.e. inter-firm alliances)'. TCE suggests economic agents try to minimize transaction costs which can lead to choose the most appropriate organizational structure (Williamson, 1981). Opportunistic behavior, asset specificity, uncertainty and frequency of transactions affect transaction costs. High level of transaction costs is likely to choose hierarchical form of governance structure (i.e. internal transaction) to minimize transaction costs. TCE is justified for being a background theory of inter-firm alliances because firms can share risks, e.g., monetary investment, market and technological uncertainty by forming strategic alliance.

The motivation for inter-firm alliances based on RBV is to create potential value through coupling complementary resources (Das \& Teng, 2000). Due to characteristics of resource heterogeneity and immobility, firms' valuable, rare, imperfectly imitable and non-substitutable resources bring sustainable competitive advantages to the firms (Barney, 1991). Resources are defined as "tangible and intangible assets which are tied semi-permanently to the firm" (Wernerfelt, 1984: 172). Rare and valuable resources of firms are not perfectly inimitable and non-substitutable which encourage forming inter-firm alliances in order to exchange and share complimentary resources. Such resource characteristics provide competitive advantages to the firms when combined together. Rapid technology and market change require fast innovation. It is becoming more and more difficult to adapt to an ever changing environment with a firm's own scarce resources. This provides rationales for growing numbers of inter-firm alliances based on RBV perspective. If resources are exchanged effectively in the market place, firms will operate 
independently. However, not all resources are exchanged in the market place and some resources are tied in firms making it difficult for firms to exchange resources through the market place (Chi, 1994).

The theoretical background of technological alliance motivation applied in this study are TCE and RBV perspectives. Cost reduction in product development and combination of complementary resources are often strong motivation for firms to enter into strategic alliance (Das \& Teng, 2000; Hagedoorn, 2002; 2006). From the institutional economics point of view, TCE is based on firms outside competitive environment aiming at minimizing the cost of transactions, but RBV focuses on the firm's internal competitiveness for full utilization of resources (Das \& Teng, 2000). TCE focuses on efficiency of transactions and does not provide explanation for value creation through exchanging, exploiting resources by inter-firm alliances (Henderson \& Clark, 1990; Lai \& Chang, 2010; Pisano, 1990). Launching products or services first in the market is very important in high-tech industry. Many times high-tech firm's strategy focuses on shortening time to market, converging bundle of diverse technologies into new products which can be explained by RBV rationale but not TCE. However, high-tech industry such as semi-conductor, new drug development and aero-space which demand huge amount of specific asset investment provide strong motivation for cost sharing and risk hedging through inter-firm alliances. TCE provides sound rationales in these business environments than RBV does. Therefore, we suggest it will provide much better insights if we treat TCE and RBV complimentarily rather than competitively (see Silverman 1998).

\subsection{RESEARCH HYPOTHESE}

Alliance partners can vary depending on firm's motivation for forming inter-firm alliance (Dong \& Glaister, 2006; Nielsen, 2003). If the alliance motivation is to reduce R\&D costs and increase efficiency, firms will choose alliance partners based on TCE perspective. If the motivation behind the alliance is to complement R\&D capabilities or affect the inflow of outside technologies for new product development, firms will likely choose alliance partners based on the RBV perspective. From these arguments, technological alliance motivation based on TCE and RBV perspectives will impact on the selection of technological partner. Broadly there are two selection criteria in alliance partner; task-related and partner-related criteria. These are generally accepted by most researchers and used as key measures for selection of alliance partners (Cummings \& Holmberg, 2012; Dong \& Glaister, 2006; Nielsen, 2003; Geringer, 1991; Glaister, 1996). Hence,

Hypothesis 1: Technological alliance motivation (here, TCE and RBV perspectives) will impact on the selection of technological partners.

TCE suggests if asset specificity, uncertainty and risk of opportunism are high, firms need to select strong control mechanisms such as equity joint ventures (EJVs) (Das \& Teng, 2000; Oxley \& Sampson, 2004; Williamson, 1985). According to meta-analysis of David and Han (2004), asset specificity and uncertainty are found to be the most influential factors in TCE. Asset specificity is physical or intangible assets that are tied to specific transactions and cannot be moved for other purposes without loss of asset value (Buvik \& Anderson, 2002). If assets are specifically tied to certain transactions, such assets are difficult to move and heavily dependent on transacting parties. Thus, it is cost effective and safer to integrate such transactions which indicate EJVs as alliance governance structure is suggested. Uncertainty arises from external environments such as market and technology changes, partner's opportunistic behaviors. In the presence of high uncertainty, EJVs are preferred as alliance governance mode to share risks and minimize transaction costs.

Das \& Teng, (2000) assert that the characteristics of resources decide a preferable alliance governance structure. They suggested four types of alliance governance structures depending on the combination of resources of focal and partner firm, i.e., unilateral contract-based alliances, bilateral contract-based alliances, minority equity alliances and EJVs. Based on their propositions, EJVs are preferred if firms intend to capture valuable resources of partners. Tallman and Shenkar (1990) also stressed if partners 
are combining intangible resources they prefer EJVs and if combining tangible resource, they prefer contract-based alliances (i.e. Non-EJVs). So, it is expected that strong control mechanisms such as EJVs are preferred when combining valuable resources between alliance participants to safeguard leakage of valuable and legally unprotected resources. Therefore,

Hypothesis 2: Technological alliance motivation (here, TCE and RBV perspectives) will impact on the choice of alliance governance structure.

Lai \& Chang, (2010) studied the impact of alliance motivation incorporating TCE and RBV perspectives in the context of the Taiwanese machinery industry. They showed that technological motivation affected technological alliance performance. Particularly, 'asset specificity', 'uncertainty' of TCE and 'technological characteristics' of RBV showed strong positive impact on the technological alliance performance. Motivation is inherent in the nature of human characteristics. Strongly motivated person will put best efforts to carry out the tasks. And thus, employees who are strongly motivated, they are more likely to perform tasks set out in the technological alliance successfully and the performance of the alliance is likely to be high. Hence,

Hypothesis 3: Technological alliance motivation (here, TCE and RBV perspectives) will impact positively on alliance performance.

Kale \& Singh, (2000) recommended firms need to carefully design and manage each stage of inter-firm alliances in order to increase rate of alliance success. Depending on the characteristics of alliance partners, the choice of alliance governance structure can vary. Das \& Teng, (2000) also asserted that the selection of alliance partners influences the choice of alliance governance structure. A few researchers stressed the success of strategic alliance depends on the selection of appropriate alliance partners (Nielsen, 2003; Geringer, 1991; Rai, Borah, \& Ramaprasad, 1996; Wu, Shih, \& Chan, 2009). Furthermore, Sampson (2004) showed the alliance governance structure aligned with TCE perspective generated $138 \%$ higher alliance performance than the misaligned one, demonstrating the alliance governance structure may have impact on the alliance performance. Based on the above rationales, we hypothesize as below.

Hypothesis 4: Technological alliance partner selection will impact on the choice of alliance governance structure.

Hypothesis 5: Technological partner selection will impact on the performance of technological alliance.

Hypothesis 6: Depending on the alliance governance structure (i.e. EJVs or Non-EJVs), the alliance performance will vary.

\subsection{METHOD}

\subsection{SAMPLE}

This study surveyed and collected data from Korean manufacturing high technology ventures that formed technological alliance from 2008 to 2012. A total of 1,870 high technology venture firms were contacted and 215 companies answered (11.5\% response rate). The average 3 year revenue is 21Mil USD, while 3 year average R\&D investment is 0.84 Mil USD and thus R\&D intensity average is about $3.9 \%$. The average number of employees is 96 . The fields of technological alliance are information technology (63 cases), biotechnology (35 cases), semi-conductor (11 cases), new and renewable energy (11 cases), nanotechnology ( 9 cases), new materials ( 5 cases) and other 81 cases (i.e. aerospace, optical instruments, precision instruments, etc.). We used structural equation model (SEM) to test our hypotheses.

\subsection{MEASURES}

The main constructs of this study are TCE and RBV perspectives which are used as motivation theories for alliance formation. In order to improve the accuracy of the measures, we requested responding firms 
to present a specific $R \& D$ alliance case first and answer how they perceive some specific attributes of the R\&D alliance. TCE was measured by three variables; the level of 1) human asset specificity, 2) physical asset specificity and 3) uncertainty based on Santoro \& McGill, (2005). RBV was measured using four variables; the level of 1) technology supplementability, 2) imitability, 3) technology scarcity and 4) technology value based on Das \& Teng, (2000). A 7 point Likert scale was adapted to measure TCE and RBV variables of respondents' perception on the specific alliance.

The construct of technological alliance partner selection was measured based on studies by Cummings \& Holmberg, (2012). Most researchers use two criteria to measure appropriability of alliance partners; task-related and partner-related criteria. Nine items were used to measure the technological alliance partner selection criteria; four items to measure task-related and five items to measure partner-related criteria using a 7 point Likert scale.

The type of alliance governance structure is broadly classified into two folds; equity joint ventures (EJVs) and contract-based alliances (i.e. Non-EJVs) (see Das \& Teng, 2000; Lai \& Chang, 2010). We followed this convention and measured the alliance governance mode as dummy variable (EJVs=1, Non-EJVs=0).

Alliance performance is measured in a various ways such as alliance sustainability (Beamish, 1987), profits generated from alliance (Reuer \& Miller, 1997), and achievement of new product development goal by alliance (Deeds \& Hill, 1996). Some researchers go further to measure alliance success using proxies such as stock value increase (Kale, Dyer, \& Singh, 2002; Kohers \& Kohers, 2000). Since Gulati (1998) cautioned exclusive use of financial measurement, we adopted 3 items from the items used in Lai \& Chang, (2010) including financial and non-financial measures that indicate alliance success based on the perception of the respondents using a 7 point Likert scale. The measurement of variables used in this study is listed in Table 1.

Table 1: Constructs and measures

\begin{tabular}{|c|c|c|c|}
\hline Constructs & Variables & Measurement Items (coded name) & Reference \\
\hline \multirow[t]{2}{*}{$\begin{array}{l}\text { Alliance } \\
\text { Motivation }\end{array}$} & TCE & $\begin{array}{l}\text { 1. Co-invested equipment (TCE1) } \\
\text { 2. Co-invested research facilities (TCE2) } \\
\text { 3. Dispatch of researchers to the partner firm (TCE3) } \\
\text { 4. Competent researchers put into the project (TCE4) } \\
\text { 5. Uncertainty of tasks (TCE5) } \\
\text { 6. Uncertainty of partners (TCE6) } \\
\text { 7. Uncertainty of technology (TCE7) } \\
\text { 8. Uncertainty of market (TCE8) }\end{array}$ & $\begin{array}{l}\text { Santoro \& } \\
\text { McGill (2005) }\end{array}$ \\
\hline & RBV & $\begin{array}{l}\text { 1. Complementarity of firm's technology (RBV1) } \\
\text { 2. Technology inimitability (RBV2) } \\
\text { 3. Technology value (RBV3) } \\
\text { 4. Technology scarcity (RBV4) }\end{array}$ & $\begin{array}{l}\text { Das \& Teng } \\
(2000)\end{array}$ \\
\hline $\begin{array}{l}\text { Technological } \\
\text { Alliance Partner } \\
\text { Selection }\end{array}$ & $\begin{array}{l}\text { Partner- } \\
\text { related } \\
\text { Criteria }\end{array}$ & $\begin{array}{l}\text { 1. Partner's technology knowhow (TRC1) } \\
\text { 2. Partner's human resource (TRC2) } \\
\text { 3. Partner's intellectual properties (TRC3) } \\
\text { 4. Shorting product time to Market (TRC4) } \\
\text { 1. Sharing common goal and value (PRC1) } \\
\text { 2. Problem solving will (PRC2) } \\
\text { 3. Understanding firm's culture (PRC3) } \\
\text { 4. Alliance management system (PRC4) } \\
\text { 5. Trust between Top management (PRC5) }\end{array}$ & $\begin{array}{l}\text { Cummings \& } \\
\text { Holmberg } \\
(2012)\end{array}$ \\
\hline
\end{tabular}


Governance Structure

Performance
Equity-based Ventures or Non-EJV (GOV)

Das \& Teng (2000)

1. Increase of revenue, stock value, productivity or cost reduction (AP1)

2. Alliance goal achievement (AP2)

3. Firm's capability enhancement (AP3)
Lai \& Chang

(2010)

\subsection{RESULTS}

\subsection{EXPLORATORY FACTOR ANALYSIS}

The construct validity of the variables was examined using the approach of exploratory factor analysis. This analysis adopts principal component analysis as the extracting factors and Varimax as the rotation method. This study accepted items exceeding Rigenvalue more than 1.0 and factor loading more than 0.40. The results indicate that Eigen values of actors extracted greater than one. Items were loaded on the construct variables as expected. The results of the percentage of variance revealed that more than $74 \%$ of the variance of the items analyzed can be explained by the factors extracted, implying strong significance of the factors extracted. One item (coded 'RBV 1') in RBV variable was removed due to the low factor loading value (0.380). Also one item (coded 'PRC 5') of partner-related criteria item was removed due to the low factor loading value (0.397) as well. The results are presented in Table 2. All items of factor loadings are over 0.60 and Cronbach's alphas are more than 0.70 which suggest strong construct reliability of the data.

Table 2: Exploratory factor analysis

\begin{tabular}{|c|c|c|c|c|c|c|c|c|c|c|}
\hline \multirow{2}{*}{$\begin{array}{l}\text { Variables } \\
\text { (Coded name) }\end{array}$} & \multirow{2}{*}{ Items } & \multicolumn{7}{|c|}{ Factors } & \multirow{2}{*}{ Reliability1) } & \multirow{2}{*}{ Explained2) } \\
\hline & & 1 & 2 & 3 & 4 & 5 & 6 & 7 & & \\
\hline \multirow{2}{*}{$\begin{array}{l}\text { Specific } \\
\text { Facilities (SF) }\end{array}$} & TCE1 & .000 & .026 & .002 & 199 & .359 & .224 & .756 & \multirow{2}{*}{0.730} & \\
\hline & TCE2 & .002 & .156 & .083 & .087 & -.013 & .054 & .907 & & \\
\hline \multirow{4}{*}{$\begin{array}{l}\text { Specific } \\
\text { Human } \\
\text { Resources (SHR) }\end{array}$} & TCE3 & .055 & .168 & .180 & .053 & .096 & .821 & .145 & \multirow[b]{2}{*}{0.731} & \\
\hline & )$^{\mathrm{TCE} 4}$ & -.011 & .161 & .191 & .086 & .144 & .834 & .076 & & \\
\hline & TCE5 & .692 & .027 & -.256 & .094 & -.027 & .016 & .116 & \multirow{6}{*}{0.868} & \\
\hline & TCE6 & .788 & -.252 & -.087 & -.223 & -.045 & .131 & -.003 & & \\
\hline \multirow{4}{*}{$\begin{array}{l}\text { Uncertainty } \\
\text { (UCT) }\end{array}$} & TCE7 & .818 & -.107 & -.132 & -.090 & -.050 & -.007 & .020 & & \\
\hline & TCE8 & .796 & -.214 & -.156 & -.172 & -.082 & .031 & .005 & & \\
\hline & TCE9 & .645 & -.081 & .116 & -.326 & -.090 & -.131 & -.085 & & \\
\hline & TCE10 & .792 & .064 & -.181 & .053 & -.011 & -.035 & -.082 & & \\
\hline \multirow{3}{*}{$\begin{array}{l}\text { Resource } \\
\text { Value } \\
(\mathrm{RV}) 3)\end{array}$} & $\mathrm{RBV} 2$ & -.060 & .149 & .140 & .131 & .829 & .120 & .089 & \multirow{3}{*}{0.839} & \\
\hline & $\mathrm{RBV}_{3}$ & -.209 & .260 & .173 & .229 & .724 & .163 & -.049 & & \\
\hline & $\mathrm{RBV}_{4}$ & .004 & 190 & .075 & .101 & .862 & .026 & .182 & & \\
\hline \multirow{4}{*}{$\begin{array}{l}\text { Task- } \\
\text { Related } \\
\text { Criteria } \\
\text { (TRC) }\end{array}$} & $\mathrm{TRC} 1$ & -.158 & .766 & .303 & .147 & .156 & .184 & .024 & \multirow{4}{*}{0.891} & \\
\hline & $\mathrm{TRC2}$ & -.163 & .794 & .303 & .180 & .130 & .163 & .041 & & \\
\hline & $\mathrm{TRC} 3$ & -.064 & .794 & .200 & .088 & .238 & .043 & .149 & & \\
\hline & $\mathrm{TRC}_{4}$ & -.089 & .647 & .307 & .308 & .241 & .157 & .085 & & \\
\hline \multirow{3}{*}{$\begin{array}{l}\text { Partner- } \\
\text { Related } \\
\text { Criteria }\end{array}$} & PRC1 & -.213 & .306 & .746 & .219 & .133 & .124 & -.031 & \multirow{3}{*}{0.951} & \\
\hline & $\mathrm{PRC} 2$ & -.206 & .247 & .812 & .249 & .132 & .158 & .002 & & \\
\hline & $\mathrm{PRC}_{3}$ & -.221 & .281 & .789 & .175 & .115 & .172 & .073 & & \\
\hline
\end{tabular}




\begin{tabular}{lllllllll}
\hline (PRC)3) & PRC4 & -.191 & .394 & .674 & .128 & .135 & .163 & .151 \\
Alliance & AP1 & -.113 & .123 & .127 & .843 & .111 & .088 & .168 \\
Performance & AP2 & -.163 & .185 & .244 & .792 & .117 & .049 & .080 \\
(AP) & AP3 & -.137 & .241 & .292 & .772 & .292 & .034 & .050
\end{tabular}

0.881

1) Cronbach's a value, 2) Percentage of Variance Explained, 3) RBV1 and RPC5 were removed due to low factor loadings

\subsection{TEST OF CONVERGENT VALIDITY AND DISCRIMINANT VALIDITY}

We also assessed the convergent and discriminant validity of the constructs. For construct reliability (CR), we used $\lambda$ loading and its significance of $t$-value. Table 3 summarizes all $\lambda$ loadings and $t$-values which are significant at $p<0.001$. CR values of all items are over 0.6 and average variance extracted (AVE) are over 0.5 which meet the standard proposed by Bagozzi and Yi (1988), establishing convergent validity. As for discriminant validity, the squared correlation of various constructs should not exceed the value of construct's AVE (Fornell \& Lacker, 1981). Table 4 reports the correlation, standard errors and squared value of constructs. AVEs of all constructs exceed the squared correlation of various constructs and all confidence intervals of $\Phi$ coefficient which provides evidence of discriminant validity.

Table 3: Test results on convergent validity

\begin{tabular}{|c|c|c|c|c|}
\hline Variables & Items & $\lambda$ Loadings & C.R. & AVE \\
\hline \multirow{2}{*}{ Specific Facilities (SF) } & TCE1 & $1.139 * * *$ & \multirow{2}{*}{0.823} & \multirow{2}{*}{0.727} \\
\hline & TCE2 & $0.507^{* * *}$ & & \\
\hline \multirow{2}{*}{ Specific HR (SHR) } & TCE3 & $0.760 * * *$ & \multirow{2}{*}{0.838} & \multirow{2}{*}{0.814} \\
\hline & TCE4 & $0.775 * * *$ & & \\
\hline \multirow{6}{*}{ Uncertainty (UCT) } & TCE5 & $0.600 * * *$ & \multirow{6}{*}{0.851} & \multirow{6}{*}{0.857} \\
\hline & TCE6 & $0.854^{* * *}$ & & \\
\hline & TCE7 & $0.804^{* * *}$ & & \\
\hline & TCE8 & $0.847^{* * *}$ & & \\
\hline & TCE9 & $0.581 * * *$ & & \\
\hline & TCE10 & $0.674^{* * *}$ & & \\
\hline \multirow{3}{*}{ Resource Value (RV) } & $\mathrm{RBV} 2$ & $0.806 * * *$ & \multirow{3}{*}{0.946} & \multirow{3}{*}{0.900} \\
\hline & $\mathrm{RBV}_{3}$ & $0.779 * * *$ & & \\
\hline & $\mathrm{RBV}_{4}$ & $0.819 * * *$ & & \\
\hline \multirow{4}{*}{$\begin{array}{l}\text { Task-related } \\
\text { Criteria (TRC) }\end{array}$} & TRC1 & $0.864 * * *$ & \multirow{4}{*}{0.974} & \multirow{4}{*}{0.932} \\
\hline & TRC2 & $0.888 * * *$ & & \\
\hline & $\mathrm{TRC}_{3}$ & $0.760 * * *$ & & \\
\hline & $\mathrm{TRC}_{4}$ & $0.779 * * *$ & & \\
\hline \multirow{4}{*}{$\begin{array}{l}\text { Partner-related } \\
\text { Criteria (PRC) }\end{array}$} & PRC1 & $0.853 * * *$ & \multirow{4}{*}{0.984} & \multirow{4}{*}{0.953} \\
\hline & $\mathrm{PRC2}$ & $0.913^{* * *}$ & & \\
\hline & $\mathrm{PRC} 3$ & $0.879 * * *$ & & \\
\hline & $\mathrm{PRC}_{4}$ & $0.798 * * *$ & & \\
\hline \multirow{3}{*}{$\begin{array}{l}\text { Alliance } \\
\text { Performance (AP) }\end{array}$} & AP1 & $0.750 * * *$ & \multirow{3}{*}{0.961} & \multirow{3}{*}{0.920} \\
\hline & $\mathrm{AP} 2$ & $0.833^{* * *}$ & & \\
\hline & $\mathrm{AP}_{3}$ & $0.944^{* * *}$ & & \\
\hline $\begin{array}{l}\chi 2=437.584(p=0.000, \quad d f=248) \\
R M S E A=0.060\end{array}$ & $C M I N / D F=1.764$ & , TLI=0.921, & $\mathrm{CFI}=0.940, \quad \mathrm{NFI}=0.875$ & $|F|=0.941$ \\
\hline${ }^{* * *}$ significant at $\mathrm{p}<0.001$ & & & & \\
\hline
\end{tabular}


Table 4: Test results on discriminant validity

\begin{tabular}{|c|c|c|c|c|c|c|c|}
\hline $\begin{array}{l}\text { Variables } \\
(\mathrm{N}=215)\end{array}$ & SF & SHR & UCT & RV & TRC & PRC & AP \\
\hline SF & & 0.115 & 0.002 & 0.175 & 0.042 & 0.022 & 0.082 \\
\hline SHR & $\begin{array}{r}0.339 \\
(0.066)\end{array}$ & & 0.003 & 0.171 & 0.262 & 0.260 & 0.104 \\
\hline UCT & $\begin{array}{r}-0.049 \\
(0.033)\end{array}$ & $\begin{array}{c}-0.052 \\
(0.065)\end{array}$ & & 0.071 & 0.167 & 0.235 & 0.168 \\
\hline $\mathrm{RV}$ & $\begin{array}{r}0.418 \\
(0.081)\end{array}$ & $\begin{array}{r}0.413 \\
(0.091)\end{array}$ & $\begin{array}{r}-0.267 \\
(0.072)\end{array}$ & & 0.319 & 0.213 & 0.303 \\
\hline TRC & $\begin{array}{r}0.204 \\
(0.050)\end{array}$ & $\begin{array}{r}0.515 \\
(0.089)\end{array}$ & $\begin{array}{r}-0.409 \\
(0.072)\end{array}$ & $\begin{array}{r}0.565 \\
(0.093)\end{array}$ & & 0.558 & 0.361 \\
\hline PRC & $\begin{array}{r}0.148 \\
(0.038)\end{array}$ & $\begin{array}{r}0.510 \\
(0.076)\end{array}$ & $\begin{array}{r}-0.485 \\
(0.065)\end{array}$ & $\begin{array}{r}0.461 \\
(0.076)\end{array}$ & $\begin{array}{r}0.747 \\
(0.082)\end{array}$ & & 0.365 \\
\hline AP & $\begin{array}{r}0.287 \\
(0.057)\end{array}$ & $\begin{array}{r}0.322 \\
(0.078)\end{array}$ & $\begin{array}{r}-0.410 \\
(0.070)\end{array}$ & $\begin{array}{r}0.550 \\
(0.091)\end{array}$ & $\begin{array}{r}0.601 \\
(0.087)\end{array}$ & $\begin{array}{r}0.604 \\
(0.075)\end{array}$ & \\
\hline
\end{tabular}

Under the diagonal is the correlation of constructs and parenthesis is S.E (Standard Error). Upper the diagonal is squared correlation of various constructs.

\subsection{CONFIRMATORY FACTOR ANALYSIS}

We then performed confirmatory factor analysis to test unidimensionality of items. As for the fit indices of the analysis performed, the analysis indicates that, except for the significance value of $\chi^{2}(437.584$, $\mathrm{p}=0.000$ ), indices generally met the good-fit criteria. Fit indices showed $\mathrm{CFI}=0.940, \mathrm{TLI}=0.921, \mathrm{NFI}=0.875$, RMSEA $=0.060$ implying that the model provides a satisfactory fit.

\subsection{SEM ANALYSES AND HYPOTHESES TESTING}

The SEM model we tested is depicted in Figure 1.

Figure 1: SEM of TCE and RBV as alliance motivation on partner selection, governance and performance

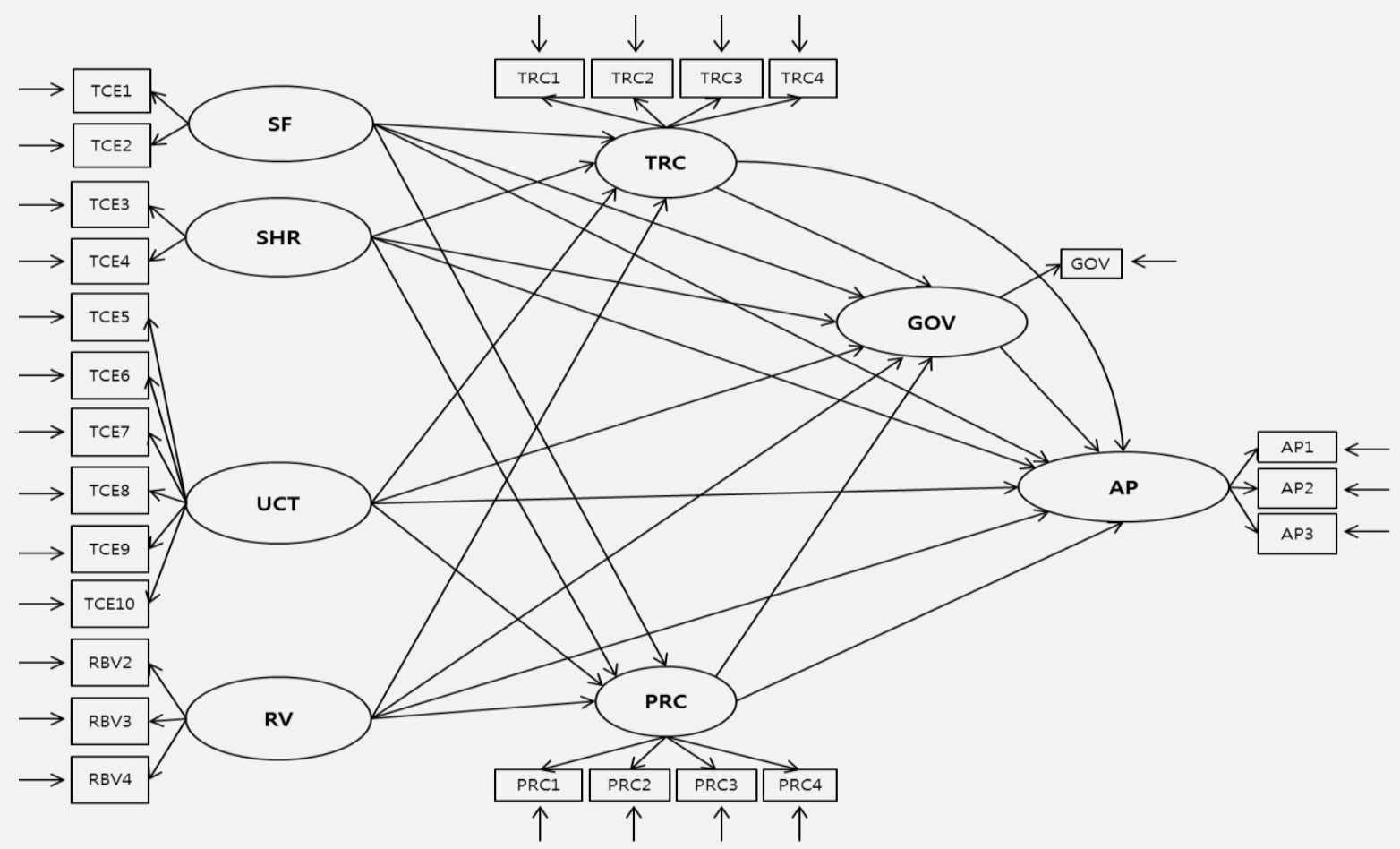


Table 5 shows the results of SEM test such as path coefficients, significance and t-value. The paths to technological partner selection criteria from alliance motivation were highly significant (Hypothesis 1). These results lend support to Hypothesis 1 . We tested the path coefficients of alliance governance choice influenced by alliance motivation (Hypothesis 2). The result demonstrates that none of the paths are significant. Therefore, it does not support hypothesis 2. The third test was the paths from technological alliance motivation to alliance performance (Hypothesis 3). SF variable of TCE and RV variable of RBV showed significant positive effects. Thus we found partial support for Hypotheses 3. Regarding the test of the paths from technological partner selection criteria to alliance governance structure choice (Hypothesis 4), there was no significant paths. Thus we reject Hypothesis 4. The paths from technological partner selection criteria to alliance performance had positive significant effects, supporting Hypothesis 5. The test of alliance governance structure to alliance performance showed no significant value and thus it did not support Hypothesis 6.

Table 5: Results of Structural Equation Model (SEM)

\begin{tabular}{|c|c|c|c|c|}
\hline Paths & & Path Coefficients & & t-value \\
\hline$\gamma \mathrm{SF} \rightarrow \mathrm{TRC}$ & & $-0.206 *$ & & -2.228 \\
\hline$\gamma \mathrm{SF} \rightarrow \mathrm{PRC}$ & & $-0.214 * * *$ & & -2.641 \\
\hline$\gamma \mathrm{SHR} \rightarrow \mathrm{TRC}$ & & $0.647 * * *$ & & 6.010 \\
\hline$\gamma \mathrm{SHR} \rightarrow \mathrm{PRC}$ & & $0.609 * * *$ & & 6.238 \\
\hline$\gamma \mathrm{UCT} \rightarrow \mathrm{TRC}$ & & $-0.387 * * *$ & & -4.848 \\
\hline$\gamma \mathrm{UCT} \rightarrow \mathrm{PRC}$ & & $-0.444 * * *$ & & -6.029 \\
\hline$\gamma \mathrm{RV} \rightarrow \mathrm{TRC}$ & & $0.289 * * *$ & & 3.684 \\
\hline$\gamma \mathrm{RV} \rightarrow \mathrm{PRC}$ & & $0.136 *$ & & 2.018 \\
\hline$\gamma \mathrm{SF} \rightarrow \mathrm{GOV}$ & & 0.089 & & 1.743 \\
\hline$\gamma \mathrm{SHR} \rightarrow \mathrm{GOV}$ & & 0.062 & & 0.658 \\
\hline$\gamma \mathrm{UCT} \rightarrow \mathrm{GOV}$ & & 0.043 & & 0.744 \\
\hline$\gamma \mathrm{RV} \rightarrow \mathrm{GOV}$ & & -0.019 & & -0.469 \\
\hline$\gamma \mathrm{SF} \rightarrow \mathrm{AP}$ & & $0.211 *$ & & 2.081 \\
\hline$\gamma \mathrm{SHR} \rightarrow \mathrm{AP}$ & & -0.171 & & -0.930 \\
\hline$\gamma \mathrm{UCT} \rightarrow \mathrm{AP}$ & & -0.086 & & -0.762 \\
\hline$\gamma \mathrm{RV} \rightarrow \mathrm{AP}$ & & $0.214 * * *$ & & 2.621 \\
\hline$\beta \mathrm{TRC} \rightarrow \mathrm{GOV}$ & & -0.105 & & -1.754 \\
\hline$\beta \mathrm{PRC} \rightarrow \mathrm{GOV}$ & & 0.065 & & 0.932 \\
\hline$\beta \mathrm{TRC} \rightarrow \mathrm{AP}$ & & $0.235^{*}$ & & 2.025 \\
\hline$\beta \mathrm{PRC} \rightarrow \mathrm{AP}$ & & $0.383 * * *$ & & 2.777 \\
\hline$\beta \mathrm{GOV} \rightarrow \mathrm{AP}$ & & 0.034 & & 1.496 \\
\hline Model Fit & $\begin{array}{l}X^{2}=469.778 \\
I F I=0.932\end{array}$ & $\chi^{2} / \mathrm{df}=1.887, \quad C F I=0.930$ & RMSEA =0.064, & $\mathrm{NFI}=0.865$ \\
\hline
\end{tabular}

\subsection{CONCLUSION}

In this paper, we sought to understand the exploratory power of alliance motivational theories, TCE and RBV, on technological alliance formation among Korean manufacturing high technology ventures. Technological alliances are important tactics for enhancing capabilities of firm innovation. This strategic approach provides firms with risk hedging, fast time to market and learning new knowledge among other advantages. Even though a number of forming technological alliances are increasing, little attention has been paid to the linkage between technological alliance motivation and formation. This study adopted two of the most widely accepted alliance motivational theories, TCE and RBV, to test their effects on each stage of technological alliance.

The results show that technological alliance motivation understood through TCE and RBV perspectives 
impact the selection of partners complimentarily. In this study, uncertainty and physical asset specificity showed negative impact on the selection of partners, implying high uncertainty and investing in specific assets may increase the difficulty of choosing alliance partners. However, human asset specificity showed strong positive impact to the selection of partners, demonstrating the importance of putting competent researchers into technological alliance. Valuable resources showed positive effects on partner selection, implying the importance of valuable resources in selecting alliance partners. Conclusively, the variables of TCE impacted more on partner-related characteristics while the variables of RBV impact on taskrelated characteristics. This implies that TCE perspectives as found in the possibility of partner's opportunistic behaviors and uncertainty could be more linked with partner characteristics and RBV perspective as found in partner firm's valuable resources could be linked more with partners' resources and abilities to perform alliance tasks successfully. This study found TCE and RBV variables had positive impact on the selection of alliance partners. Technological alliance partner selection showed a positive impact on alliance performance. Specifically, partner-related criteria had more impact than task-related criteria on alliance performance, implying the importance of the selection of good fit partners (e.g. similar organization culture, values and trusts, etc.) in technological alliance is very important in high-tech industries.

\section{REFERENCES}

Bagozzi, R. P., \& Yi, Y. (1988). On the evaluation of structural equation models. Journal of the Academy of Marketing Science, 16(Spring), 74-94.

Barney, J. (1991). Firm resources and sustained competitive advantage. Journal of Management, 17(1), 99120.

Beamish, P. W. (1987). Joint ventures in LDCs: Partner selection and performance. Management International Review, 27(1), 23-37.

Buvik, A., \& Andersen, O. (2002). The impact of vertical coordination on ex post transaction costs in domestic and international buyer-seller relationships. Journal of International Marketing,10(1), 1-24.

Chen, H., \& Chen, T. (2002). Governance structures in strategic alliances: Transaction cost versus resource-based perspective. Journal of World Business, 38(1), 1-14.

Chi, T. (1994). Trading in Strategic Resources: Necessary Conditions, Transaction Cost Problems, and Choice of Exchange Structure. Strategic Management Journal, 15(4), 271-290.

Colombo, M. G. (2003). Alliance form: A test of the contractual and competence perspectives. Strategic Management Journal, 24(12), 1209-1229.

Cummings, J. L, \& Holmberg, S. R. (2012). Best-fit alliance partners: The use of critical success factors in a comprehensive partner selection process. Long Range Planning, 45, 136-159.

Das, T. K., \& Teng, B. S. (2000). A resource-based theory of strategic alliances. Journal of Management, 26(1), 31-61.

David, R. J., \& Han, S. K. (2004). A systematic assessment of the empirical support for transaction cost economics. Strategic Management Journal, 25(1), 39-58.

Deeds D. L., \& Hill, C. W. L. (1996). Strategic alliances and the rate of new product development: An empirical study of entrepreneurial biotechnology firms. Journal of Business Venturing, 11, 41-55.

Dong, L., \& Glaister, K. W. (2006). Motives and partner selection criteria in international strategic alliances: Perspectives of Chinese firms. International Business Review, 15(6), 577-600.

Fornell, C., \& Lacker, D. F. (1981). Structural equation models with unobservable variables and measurement errors. Journal of Marketing Research, 18(3), 382-388.

Geringer, J. M. (1991). Strategic determinants of partner selection criteria in international joint ventures. Journal of International Business Studies, 22(1), 41-62.

Glaister, K. W. (1996). UK-Western European strategic alliances: Motives and selection criteria. Journal of Euro-marketing, 54(4), 5-35.

Gulati, R. (1998). Alliances and networks. Strategic Management Journal, 19(4), 293-317.

Hagedoorn, J. (1990). Organizational modes of inter-firm cooperation and technology transfer. Technovation, 10(1), 17-30. 
Hagedoorn, J. (2002). Growth patterns in R\&D partnerships: An exploratory statistical study. International Journal of Industrial Organization, 21(4), 517-531.

Hagedoorn, J. (2006). Understanding the cross-level embeddedness of inter-firm partnership formation, Academy of Management Review, 31(3), 670-680.

Hagedoorn, J., \& Schakenraad, J. (1994). The effect of strategic technology alliances on company performance. Strategic Management Journal, 15(4), 291-311.

Henderson, R., \& Clark, K. (1990). Architectural innovation: The reconfiguration of existing product technologies and the failure of established firms. Administrative Science Quarterly, 35(1), 81-112.

Hitt, M. A., Dacin, M. T., Levitas, E., Arregle, J. L., \& Borza, A. (2000). Partner selection in emerging and developed market contexts: Resource-based and organizational learning perspectives. The Academy of Management Journal, 43(3), 449-467.

Kale, P., Dyer, J. H., \& Singh, H. (2002). Alliance capability, stock market response and long-term alliance success: The role of the alliance function. Strategic Management Journal, 23(8), 747-767.

Kale, P., \& Singh, H. (2009). Managing strategic alliances: What do we know now, and where do we go from here? The Academy of Management, 23(3), 45-62.

Kohers, N., \& Kohers. T. (2000). The value creation potential of high-tech mergers. Financial Analysts Journal, 56(3), 40-50.

Lai, W. H., \& Chang, P. L. (2010). Corporate motivation and performance in R\&D alliances. Journal of Business research, 63(5), 490-496.

Lee, P. K. C., Yeung, A. C. L., \& Cheng, T. C. E. (2009). Supplier alliances and environmental uncertainty: An empirical study. International Production Economics, 120(1), 190-204.

Lin, Z., Yang, H., \& Arya, B. (2009). Alliance partners and firm performance: Resource complementarity and status association. Strategic Management Journal, 30(9), 921-940.

Nielsen, B. B. (2003). An empirical investigation of the drivers of international strategic alliance formation. European Management Journal, 21(3), 301-322.

Odagiri, H. (2003). Transaction costs and capabilities as determinants of the R\&D boundaries of the firm: A case study of the ten largest pharmaceutical firms in Japan. Managerial and Decision Economics, 24, 187-211.

Oxley, J. E., \& Sampson, R. C. (2004). The scope and governance of international R\&D alliances. Strategic Management Journal, 25, 723-749.

Park, S. H., Chen, R. R., \& Gallagher, S. (2002). Firm resources as moderators of the relationship between market growth and strategic alliances in semiconductor start-ups. The Academy of Management Journal, 45(3), 527-545.

Pisano, G. P. (1990). The R\&D Boundaries of the Firm: An Empirical Analysis. Administrative Science Quarterly, 35(1), 153-176.

Rai, A., Borah, S., \& Ramaprasad, A. (1996). Critical success factors for strategic alliances in the information technology industry: An empirical study. Decision Sciences, 27(1), 141-155.

Reuer, J. J., \& Miller, K. D. (1997). Agency costs and the performance implications of international joint venture internalization. Strategic Management Journal, 18(6), 425-438.

Rothaermel, F. T., \& Alexandre, M. T. (2009). Ambidexterity in technology sourcing: The moderating role of absorptive capacity. Organization Science, 20(4), 759-780.

Rothaermel, F. T., \& Hill, C. W. L. (2005). Technological discontinuities and complementary assets: A longitudinal study of industry and firm performance. Organization Science, 16(1), 52-70.

Sampson, R. C. (2004). The cost of misaligned governance in R\&D alliances. Journal of Law, Economics and Organization, 20(2), 484-526.

Santoro, M. D., \& McGill, J. P. (2005). The effect of uncertainty and asset co-specialization on governance in biotechnology alliances. Strategic Management Journal, 26(13), 1261-1269.

Silverman, B. S. (1998). Technological resources and the direction of corporate diversification: Toward and integration of the resource-based view and transaction cost economics. Management Science, 45(8), 1109-1124.

Song, M., Droge, C., Hanvanich, S., \& Calantone, R. (2005). Marketing and technology resource complementarity: An analysis of their interaction effect in two environmental contexts. Strategic Management Journal, 26(3), 259-276. 
Tallman, S. B., \& Shenkar, O. (1990), International cooperative venture strategies: Outward investment and small firms from NICs. Management International Review, 30(4), 299-315.

Wernerfelt, B. (1984). A resource-based view of the firm. Strategic Management Journal, 5(2), 171-180.

Williamson, O. E. (1981). The economics of organization: The transaction cost approach. American Journal of Sociology, 87(3), 548-577.

Williamson, O. E. (1985). The economic institutions of capitalism. New York: Free Press.

Williamson, O. E. (1991). Comparative economic organization: The analysis of discrete structural alternatives. Administrative Science Quarterly, 36(2), 269-296.

Wu, W. Y., Shih, H. A., \& Chan, H. C. (2009). The analytic network process for partner selection criteria in strategic alliances. Expert Systems with Applications, 36(3), 4646-4653.

Yasuda, H. (2005). Formation of strategic alliances in high-technology industries: comparative study of the resource-based theory and the transaction-cost theory. Technovation, 25(7), 763-770.

Zahra, S. A., \& Hayton, J. C. (2008). The effect of international venturing on firm performance: The moderating influence of absorptive capacity. Journal of Business Venturing, 23(2), 195-220.

Zhou, X., Li, Q., Zhao, W., \& Cai, H. (2003). Embeddedness and contractual relationships in China's transitional economy. American Sociological Review, 68(1), 75-102. 